TRANS · NúM.II $\cdot 2007$

ARTICULOS $\cdot 231-243$
El estudio de textos periodisticos y de la manipulación de las noticias ha dado lugar a una importante producción investigadora en las últimas tres décadas (Fowler, Bell, Fairclough). La traducción permite a periodistas y compañias de noticias intervenir en el contenido de las mismas sin que los lectores sean conscientes de la manipulación ideológica a la que los textos han podido ser sometidos. En este artículo se lleva a cabo un análisis de dos textos concretos publicados por la CNN a través de Internet en sus versiones españolas e inglesas. El primero de ellos es un texto con un gran contenido politico al estar relacionado con la invasión de Irak, el papel de España en la misma y los atentados terroristas de Madrid. En el segundo se analizan los prejuicios sexistas que se aprecian en la versión española de un artículo sobre unos supuestos casos de violación en la Universidad de Colorado, Estados Unidos.

PALABRAS CLAVE: noticias, traducción, manipulación.

\title{
Political and Sexist Bias in News Translation: Two Case Studies
}

ROBERTO A. VALDEÓN

Universidad de Oviedo
News production and its ideological manipulation have received the attention of scholars over the past three decades (Fowler, Bell, Fairclough). One of the processes that allows news writers and corporations to influence news texts is the translation of texts since the target readers are not usually aware of how interlinguistic transformations can affect the reporting of a given news event. In this paper we examine two texts, covering the textual and lexical processes that have been carried out by the translators and the impact they have on the resulting reports. On the one hand we have selected a news item with a strong political component that has been part of international news bulletins and reporting over the past few years: the fight against Islamic terrorism and, more precisely, the Madrid connection. On the other we shall examine the ways in which a report about alleged rapes in an American university has succumbed to sexist prejudice.

KEY WORDS: News, translation, manipulation. 


\section{INTRODUCTION}

Since the r980s discourse scholars have turned their attention to the processes that affect news writing. Critical linguists have studied ideological manipulation in English news (Fowler, I99I and r996; Fairclough, r995b; Clark and Ivanic, I997) as well as the structure of news reports (van Dijk, I988; Bell, ı991; Waugh, r995). Hurtado has covered the structure of news writing in the Spanish press (2003). The study of translational processes in news writing is more recent and the contributions, although valuable, are less numerous (Kelly, I998; Bassnett, 2004). In 2005 the journal Language and Intercultural Communication issued a special volume devoted to global communication, with a number of articles devoted to the translation of global news for local markets whereas the University of Warwick runs a project entitled Translation and Global News.

This paper is the continuation of previous research into the translation of news items originally produced in English and translated into Spanish for the benefit of both European and Latin-American readers. In Valdeón (2005a) we established the strong dependence of Spanish BBCMundo texts on English BBCNews reports, BBCMundo being an Internet news service of the British Broadcasting Corporation which aims to create an international forum especially adapted to the needs and interests of Spanish speakers around the world. The study showed that many of the reports posted on BBCMundo were close translations rather than news texts specifically produced for a Spanish-speaking readership. In Valdeón (2005b) we focused on a second group of texts that had been previously identified as translated versions and analysed the strategies used by the writers to render the original items into the target language. The paper showed that no adaptation processes were carried out, tending to rely on literal renderings of the source texts. In Valdeón $2005 \mathrm{c}$ we turned to the other Anglophone service with a global reach, CNNenEspañol news, an Internet site that was cancelled altogether in 2004. The paper showed CNN's failure to (a) target news towards specific audiences, and (b) select news that are of specific interest to regional audiences for news-casting in the language of the region. The structure of the present study will draw on those findings but will focus on two specific news items in order to explore the ideological implications of the choices and changes effected in the target versions. That is, the approach will be qualitative rather than quantitative, as had been the case in the previous papers. The article is divided into three sections:

I. Firstly we shall carry out the analysis of a news item with a high political content. The text reports on the investigation into the terrorist attacks that took place in Madrid on II March 2004. The topic is of high significance both for the Spanish readers and for an international audience. Readers worldwide would be familiar with the events as well as the antecedents in the September II attacks in New York, the invasion of Iraq and the subsequent «war on terror», initiated by western governments in an attempt to crack down Islamic extremists. We shall also cover the ideological implications for text consumers belonging to a different cultural and political background.

2. Then we shall proceed to explore another news text which deals with a very different and much more localized news item: the alleged rapes carried out at the University of Colorado. The item has particular relevance for American readers, and, although raping is a crime affecting all western countries, the events are specifically American since they took place in the environment of a US university. 
3. Thirdly, we shall conclude with a reflection upon whether the strategies used by the translators consider the specificity of the target audience and the quality of the mediating process, and upon whether the interests and sensitivity of the Other are respected in the Spanish versions. We shall also focus on whether the ambivalent position of the text writers as translator, on the one hand, and news producers, on the other, is well-balanced, and the extent to which private agendas may have had an effect on the resulting text.

We should also notice that both versions were published on the same day at approximately the same time, although the Spanish texts tended to be posted slightly later than the English ones. The expression text producers (Fairclough, 1992) will be used as a superordinate to refer to writers, journalists or translators, since very often texts are produced by agencies, and later used by news websites at their own discretion, after going through various editing processes.

\section{POLITICAL BIAS IN TRANSLATION: THE CASE OF MADRID'S TERROR ATTACKS}

We now turn to analyse the first English report together with its apparent Spanish version. The aim is to reflect upon the way the shortcomings already identified in previous papers affect the final version of a full text, as it appeared on the Internet, rather than on short extracts from multifarious sources. The news item is a follow-up of Madrid's terror attacks and, consequently, has a global reach, but it also has a strong local value, as it reports in Spanish about events that occurred in Spain. Both the source and target texts are reproduced below. Paragraphs are numbered for easy reference:

\section{Texts $1 a \mathcal{E}^{2} \mathrm{I} b$}

Presunto líder de los atentados de Madrid estaría muerto (04/04/04)

I. Madrid -- El tunecino identificado por el gobierno de España como el líder del grupo que ejecutó los atentados del in de marzo en Madrid se encontraba entre los cuatro sospechosos muertos el sábado en una explosión, dijo el ministro del Interior español.

I. Los sospechosos, gritando consignas en árabe, activaron el sábado los explosivos cuando la policía los tenía rodeados en un edificio de apartamentos del suburbio madrileño de Leganés, afirmó Angel Acebes.

2. Un oficial de policía también fue muerto $y$ otros II resultaron heridos, dijo Acebes. Tres se encontraban aún hospitalizados, uno con heridas de gravedad, pero que no representaban un riesgo para su vida.

3. Cerca de I2 horas después de la explosión, la policía dijo a CNN que había hallado en una plaza de estacionamiento un vehículo que podría tener explosivos.

4. Con las recientes detenciones y las muertes del sábado, Acebes dijo que aquellos que fueron los principales responsables de los atentados del ir de marzo - que causaron la muerte de al menos I9o personas- están detenidas o muertas.

5. Los cuerpos del presunto líder del grupo, Sarhane Ben Abdelmajid Fakhet, de 35 años; Abdennabi Kounjaa, un marroquí de más de 20 años; y otra persona de esa misma nacionalidad identificado como Asri Rifat Anouar fueron encontrados entre los escombros que dejó el estallido del sábado por la noche, indicó Acebes.

6. Fakhet y Kounjaa se encontraban entre los seis sospechosos, sobre los que las autoridades españolas emitieron órdenes de arresto después de los ataques del ir de marzo. 
7. El cuarto sospechoso muerto no fue identificado, y otros dos habrían conseguido marcharse antes de que la policía acordonara el área, dijo.

234
8. Durante el operativo antiterrorista del sábado por la noche, varios helicópteros sobrevolaron el lugar con reflectores y dijeron a los residentes que permaneciesen en sus casas, según testigos. Otros fueron evacuados.

9. España ha acusado ya a I5 personas en relación con los atentados del in de marzo contra cuatro trenes de cercanías, en lo que se considera el peor ataque terrorista de España.

Io. El gobierno ha dicho que su investigación se concentra en el Grupo Combatiente Islámico Marroquí, que tendría vínculos con la red al Qaeda.

II. Seis de ellos están acusados de asesinato en masa y nueve están acusados de pertenecer a una organización terrorista o de colaborar con ella.

I2. Once de los 15 acusados son marroquíes.

(Con información de Reuters y Associated Press)

\section{Interior minister: Suspected Madrid bombing ringleader dead (04/04/04) \\ From Al Goodman}

I. Leganes, Spain (CNN) -- The Tunisian identified by the Spanish government as the ringleader of the March II bombings in Madrid was among four suspects killed Saturday in an explosion, the Spanish interior minister says.

2. The suspects, chanting in Arabic, set off the blast while police were pursuing them Saturday night at a four-story apartment building, Angel Acebes said.

3. One Spanish police officer was also killed and II were wounded, Acebes said. Three are still in the hospital, one in serious but not lifethreatening condition, Acebes said.
4. About I2 hours after the explosion, police again moved civilians back from the area, telling CNN they had found in a parking lot a vehicle that could be packed with explosives.

5. With recent arrests and Saturday's deaths, Acebes said those who made up «the central nucleus» responsible for the March II attack have been identified and are either detained or dead.

6. The bodies of the suspected Tunisian ringleader, Sarhane Ben Abdelmajid Fakhet, 35; Abdennabi Kounjaa, a Moroccan in his late 2os; and another Moroccan identified as Asri Rifat Anouar were found in the wreckage of Saturday night's blast, Acebes said.

7. The fourth suspect has not been identified, and two other suspects apparently got away before police sealed the area, he said.

8. Fakhet and Kounjaa were among six suspects for whom Spanish authorities issued arrest warrants after the March II attacks, which killed I9o people and wounded another I,80o.

9. Fakhet's body was found with an explosives belt with $2 \mathrm{~kg}$ ( 4.4 pounds) of unexploded bombs, Acebes said.

Io. The powerful blast at 9p.m. (2p.m. ET), in Leganes, a suburb about ro miles south of Madrid, heavily damaged the apartment building, blowing a hole through the second story.

II. Neighbors said the suspects had moved into the building after the March II attacks on commuter trains in Madrid.

I2. Acebes said Goma 2 Eco explosives -the same brand used in the March II attacks and the unexploded bomb found Friday on a high-speed rail line south of Madrid -- and 200 detonators were found in the apartment.

I3. Spanish authorities, however, have not positively linked Friday's bomb -- which would have been detonated by a long cable attached 
to it -- with the March II bombs, which were detonated by cell phone.

I4. Additionally, the Goma 2 Eco explosive is widely used in mining.

15. Eleven of the 15 people charged in the train bombings are Moroccans, and Spanish authorities have identified the Moroccan Islamic Combatant Group (GCIM) as a focus of their investigation.

I6. Acebes also said that authorities had searched a home in Grenada in connection with the March ir bombings, but he had no further information.

We shall begin by referring to the textual, grammatical and lexical errors of judgement in the first three paragraphs as examples of the shortcomings identified before (Valdeón, 2005 C). Transitivity processes have been mentioned by critical analysts as characteristic of news text writing (Fowler, I99r; Fairclough, 1992). Transitivity here does not correspond to the same concept in traditional grammars. For critical analysts this process has a key semantic component that can be foregrounded (Fowler, I991: 70-71) once the specific strategy used by the writers has been recognized, for example the use of nominalizations. News writers tend to have frequent recourse to this strategy since it allows them to imbue the texts with the ideological position of the journalists themselves or of the corporation they work for. Headlines offer good examples of transitivity processes. The headlines that introduce the item follow the same structure in both languages, with hardly any attempt to adapt it for the benefit of the target readers: the heavy noun phrase used as a subject in English (Leech \& Svartvik, 2002: 330-33I) is maintained in Spanish, although this language would require some readjustments.

The same process is repeated in the main body, with the noun phrases «El tunecino»,
«Los sospechosos» and «Un oficial de policía» respectively receiving initial focus, as in the source texts. The rest of the sentence follows the same syntactic structure, thus including certain elements that would have required further transformative processes. For instance, Spanish would require a relative clause rather than a non-finite phrase ("gritando consignas en árabe») and the order of the various complements answering the traditional whquestions in news reporting (Bell, 1991:190202) would also differ in the Spanish version. Additionally, certain English nominalizations would have required rephrasing for the Spanish audience, notably «one in serious but non life-threatening condition». The writer has had recourse to an economical but unnatural relative clause that adds nothing to «uno con heridas de gravedad.» A delition process would have been acceptable here both as an editorial routine and as a translational procedure.

As for the remaining text, the first eight paragraphs of the Spanish version correspond exactly to the source text and follow the patterns already commented upon. Paragraphs 7 and 8 have changed position. As regards syntactic and grammatical changes, the target text offers slight deviation from the original, maintaining the transitivity processes characteristic of English news discourse, resulting in foreignizing constructions (Venuti, 1995). For instance, paragraph 6 of the source text quotes Spanish Interior Minister. As a native speaker of Spanish, he is likely to have started the sentence with «se han encontrado los cuerpos de...» or «la policía ha encontrado los cuerpos de...» giving final emphasis to the new information. The reflexive «se han encontrado» or the subject «la policía» would have functioned as introductory elements 
of the main storyline, which should have received focal attention at the end of the sentence. English news discourse, on the other hand, had applied certain transformations to the words of the Spanish minister via a translational process for the benefit of the intended English readers. These changes signal the conventions of English news writing by focusing on the result of the police intervention rather than on the fact that the police are ultimately responsible for the explosions. The use of the passive voice as a transformation process is, thus, part of the hallidayian concept of transitivity in English news discourse (Fowler, 1991: 70-78).

However, the comparison of the two texts offers a very different perspective of how news discourse was constructed in the Spanish version. Acting unequivocally as a translator of the source English article, the writer has opted for imposing an English editorial strategy on the Spanish text as part of the translational process, maintaining the passive voice, the omission of the agent, and the position of the subject. Additionally, the strong punctuation marks also remain in places which would have needed other adaptations processes in the target text. That is, news writing procedures in English have superseded translational strategies and readjustments that would have accounted for the specificity of the target audience.

A second transitivity process present in the source text, that of nominalization, can be identified in paragraph 5 («those who made up «the central nucleus» responsible for the March II»). According to Fowler (I991: 79-80) and Fairclough (1995b: II2-II3), nominalizations can allow writers to imbue texts with their interpretative stance on the news event being reported by selecting the information

they regard as relevant and discarding the superfluous. However, even accepting that nominalizations can operate along the same lines in the two languages, they would require some degree of adaptation to the editorial processes characteristic of the target language. In this case the text producer of the Spanish text opts for maintaining a heavy noun phrase which results in a foreignizing (and stylistically objectionable) heavy noun phrase. The effect is additionally deteriorated through the use of another editorial routine, a relative clause with an explicatory function. The result is the sentence «...que aquellos que fueron los principales responsables de los atentados del in de marzo -que causaron la muerte de al menos I90 personas...» The text producer has modified the original source text by means of two editorial strategies: omission and addition. Firstly, the relative «... which killed I9o people...» has been omitted from its original position in paragraph 8 of the source text. The clause is included, though, in paragraph 5 of the target text, giving way to a heavy noun phrase postmodified by as many as three relative clauses. Once again, the combination of source language editorial strategies and the zeal to include all the information of the source text have superseded translational processes. This spared the target readers of clear information and adequate texts.

The target text is completed with five more paragraphs. The information in paragraphs Io, II and I3 stems directly from paragraph 15 of the source text, although it has been reshuffled, giving way to short unconnected paragraphs in the Spanish version, notably I3. The information in the other two does not derive from the source text, although, most of it can be found in two other English reports posted on the CNN at various times on the same day (and some 
sentences almost literally, for instance «varios helicópteros sobrevolaron...» was relayed from the source sentence «helicopters hovered...» in a different report).

All in all, it cannot be argued that the target text has been specifically conceived for a Spanish readership, but rather that text producers have used one particular news report as a base. This has been translated, rearranged and complemented with information from other texts published on the same day. However, the changes implemented do not consider the target culture. The item has been produced for an international audience, although it is fairer to state that it is biased towards an American readership, which implies references to the expectations and fears of the source audience such as the information about the threat the suspects posed for Spain (and, consequently, for western countries, and, consequently, to America) and the measures taken by the Spanish police to abort future actions (which parallel American actions as well). The Spanish text builds upon the same events, with scarcely any references to issues that might be relevant for local readers, and a discursive presentation based on straightforward renderings that impede easy access to the news event. Thus, the informative function expected from any news report cannot be argued to have been completely fulfilled.

\section{SEXIST BIAS IN TRANSLATION: THE CASE OF ALLEGED RAPES IN THE US}

The second text we are going to examine reports, on the other hand, on a much more localized news item: the alleged rapes carried out by some senior students at the University of Colorado. Firstly, we can challenge the choice of event to be included in a Spanish service. The crimes reported, although serious enough, have a limited appeal for an interna- tional audience, let alone European readers, more likely to be interested in events taking place in their own countries. Having said that, adequate adaptation processes aimed at making the text more natural and understandable for the readers are rare in the Spanish version. The target headline reads «No presentan cargos en investigación de agresiones sexuales en Colorado» following the English headline "No charges filed in U. of Colorado sex assualt probe» (II/05/O4). Thus, once again, the rendering makes few adjustments and does not consider the need to introduce the topic for a foreign audience. Readers are supposed to be familiar with the issue from the start. In the Spanish headline, «University» has been omitted, obscuring the reference to the actual content of the storyline. This only adds to the faulty construction of the Spanish headline, featuring the omission of articles («[la] investigación») and the lack of a subject. All in all, the sentence fails to perform the informative function of headlines (Bell, I99I). As for the main body of the report, the translators have carried out various types of adaptations with different results on the target text. Let us consider the full articles before continuing:

\section{Texts $2 a$ \& $2 b$}

\section{No presentan cargos en investigación de agresiones sexuales en Colorado}

I. Denver, Estados Unidos (AP) -- El fiscal general del estado de Colorado dijo el martes que no presentará cargos criminales en nueve casos de presuntas agresiones sexuales que involucran a jugadores de fútbol americano de la Universidad de Colorado.

2. El fiscal general Ken Salazar, nombrado fiscal especial por el gobernador Bill Owens a raíz 
del escándalo, dijo que «una completa revisión» del caso realizada por su equipo les llevó a tomar la decisión unánime de no presentar cargos.

238
3. "Como sucede con muchas investigaciones criminales, estos asuntos seguirán abiertos en el caso de que la naturaleza de las pruebas de la acusación de agresión sexual cambie en el futuro», dijo Salazar en un comunicado.

4. Agregó que no se podía proceder con los casos por problemas con las evidencias o falta de voluntad de las presuntas víctimas para seguir adelante, o ambos motivos.

5. El equipo de Salazar continuará con su investigación sobre otros posibles casos criminales que involucran al equipo de fútbol americano de Colorado y su programa de reclutamiento.

6. La universidad y un panel de la junta rectora también investiga las acusaciones de que se utilizó sexo y alcohol para atraer reclutas al campus de Boulder.

7. Por lo menos ocho mujeres han acusado de violación a jugadores o reclutas desde 1997, aunque no se presentaron cargos criminales. La declaración de Salazar no explicó el noveno caso.

8. Tres de las mujeres han demandado a la universidad ante una corte federal, argumentando que el no haber puesto freno a los atletas posibilitó las violaciones en $200 \mathrm{I}$.

\section{No charges filed in U. of Colorado sex assualt probe}

I. Denver, Colorado (AP) -- Colorado's attorney general decided against criminal charges Tuesday in nine alleged sexual assaults involving University of Colorado football players, blaming evidence concerns and the reluctance of women to go forward with the cases.

2. Attorney General Ken Salazar, tapped as a special prosecutor by Gov. Bill Owens at the height of the recruiting scandal in February, said a «thorough review» by his task force resulted in a unanimous decision against charges.

3. The decision was «based upon evidentiary considerations and-or the expressed wishes of some victims not to be subjected to the criminal justice process,» Salazar said.

4. Salazar, who did not immediately return a call seeking comment, said the probe would remain open. The task force will also continue its investigation concerning other potential criminal matters involving the Colorado football team and its recruiting program.

5. The university and a Board of Regents panel are also investigating allegations that sex and alcohol were used to entice recruits to the Boulder campus. At least eight women had accused football players or recruits of rape since I997, though no criminal charges were filed.

6. There was no immediate explanation for the ninth case referred to by Salazar.

7. Three of the women have sued the school in federal court, saying its failure to rein in the athletes contributed to their rapes in 200I. They claim the rapes constituted a hostile environment for women in violation of federal laws guaranteeing equal access to education. They are seeking unspecified damages and sweeping changes at the school.

8. Football coach Gary Barnett has been suspended with pay for comments he made about at least one of the women.

The content of the source text has been rearranged for the target audience although the reasons are not clear. For instance, paragraph 3 in the English version substantiates the decision taken by the attorney general whereas in the target text is relegated to paragraph 4 . The position of the paragraphs is generally altered without any apparent justification. Among the noteworthy strategies used by the translators 
we can mention the addition of modifying elements («football players» becomes «jugadores de fútbol americano»), substitution processes («the expressed wishes of some victims not to be subjected to the criminal justice process» becomes «falta de voluntad de las presuntas víctimas para seguir adelante») or literal renderings («recruits» becomes «reclutas», and «evidence» is translated as «evidencias»). With the exception of the first strategy in paragraph I, which, by restricting the semantic value of the term, projects the accurate image onto the target text consumers, the other two are far less successful.

The substitution process in the second example goes well beyond the need for rephrasing the source text and alters the message in a more than dubious way. First of all, the choice is for superordinate expressions (e. g. «criminal justice process» becomes «seguir adelante») that mitigate the strength of the English noun phrase. Secondly, the original "victims» is premodified by "presuntas» in the target text, which weakens the position of the patients, a term used in critical analysis of news texts to refer to those that have "suffered» the effects or consequences of the event (Fowler, I99r: 75) vis-à-vis the actors, or those that carry out the actions (that is, the football players here). Besides, the adjective «presuntas» is used in Spanish legal jargon to describe the accused, not the victims of a crime. The combination of these translational processes in the target text clearly undermines the position of the «victims» within the storyline. The head of the heavy noun phrase, «the expressed wishes of some victims not to be subjected», asserts the right of the victims not to endure a painful judicial process, whereas the Spanish version emphasizes the negative interpretation of the text producer by using «la falta de voluntad» («unwillingness»). That is, while the source text projects a resolute image of the victims, the target text opts for presenting a negative view of the patient, which, in its turn, reinforces the position of the actors, the alleged rapists, as victims of some type of obscure conspiracy.

Paragraphs 4 and 5 in the English text also provide information about future actions to be taken by the attorney and by university authorities investigating the ways in which new students are attracted towards their programmes. There is a tendency towards the use of legal jargon («potential criminal matters», «investigating allegations», "no criminal charges were filed») as well as rather formal lexicon («entice recruits»). Conversely, the Spanish text positions the women negatively by reiterating the fact that they «accused» someone («acusación de agresión sexual» in paragraph 3 , «investiga las acusaciones» in paragraph 6 and «ocho mujeres han acusado de violación» in paragraph 8 ). The accusations are pictured against the lack of evidence pointed out by the attorney and, therefore, the position of the women is undermined once again.

Finally, we should point out two cases of deletion that are worth commenting upon. Deletion is a strategy that implies the elimination of those elements that are believed to be irrelevant for the target readers. Relative sentences or heavy noun phrases can be used in English news writing with an explanatory function when reporting on foreign institutions or companies. For instance, the BBC reported on the hostile takeover of Gas Natural over Endesa thus: «The Spanish government has given approval to Gas Natural's 22.4bn euro (\$27bn; £ I $5 \mathrm{bn})$ hostile takeover of fellow Spanish energy company Endesa» (03/02/2006). The Gas company did need an introduction since the name was sufficiently clear for 
Anglophone readers, but Endesa did require some degree of explanation if the target readership was to understand the news item. BBCMundo omitted it in its Spanish version since the company is obviously well-known in Spain, but also in Latin-America. As for the two texts under scrutiny, the deletion cases that we have noted, however, cannot be explained on the same grounds. In paragraph 7 the original article refers to the claims made by the women that gender is still a deterrent for them when trying to have access to academic life, and that sex remains embedded within the institution as a means to an end. The target text has omitted this critical interpretation of the events altogether. The second omission is the brief concluding paragraph whereby readers are informed of the suspension of the team's coach for the comments he made about the women. Although the content of those comments is not explicited, readers can safely assume that his words could have been openly sexist. The Spanish version deleted this last sentence altogether.

Thus, all the translational strategies used in this second text point in the direction of a transformation of the source text in a manner that could be easily challenged and interpreted as sexist. The victims have almost been deprived of their role as patients in the news item whereas the role of the alleged rapists has been repositioned from actors (that is, those that could be held responsible for the news event) to likely sufferers of unjust accusations.

\section{FINAL DISCUSSION}

In previous research we established that both the $\mathrm{BBC}$ and the CNN had recourse to translated versions of their own original English news texts for their so-called Spanish services. The deficiencies we encountered derived from

a quantitative approach that provided us with the main strategies used by text producers, and we proposed taxonomies of the most frequent ones. The approach in this paper has been qualitative and attempted to decide upon whether those strategies had an overall influence on two given articles, that is, we have dealt with two case studies: the first one reporting on political issues of great relevance for an international readership whereas the second article dealt with a sensitive issue in western societies. However, the choice did not truly have the international scope that would have been advisable in a global service concerned with the interests of the Spanish-speaking readers. The launching of CNNenEspañol indicated the importance of the Spanish audience for the news company at that time, although the corporation did not seem to have a well-defined policy towards its Spanish news portal and its likely readership worldwide $(2005 \mathrm{c})$. As stated, it is debatable whether some of the items posted should have been included at all.

However, our main concern here is the quality of the service and the influence of the writers/translators on the texts they manipulated. Even if most of the original content remained, the texts underwent thorough transformations, such the re-organization of the news events (including the order of the paragraphs) as well as additions, omissions and substitutions. These strategies allowed the translators to imbue the final product with their own ideological stance, as clearly exemplified by the report on the alleged rapists in the University of Colorado. This point is not without relevance since it is related to the role that the text producer plays when reporting on a concrete news event. We are not going to enter the debate about the objectivity of the press in news reporting or about the role journalists and news corporations play in the 
construction of a certain illusion of a parallel reality when reporting on those events. But it is worth mentioning that $\mathrm{CNN}$ writers/translators might have easily taken advantage of their role as mediators between two cultures to project certain interpretations of the events they were translating. It is at this point that we may introduce a distinction between the role of the translators of these texts as true mediators, understood as in Translation Studies (Hatim and Mason, 1990 and 1997), or only as intermediaries between the news event, the news corporation and the text consumers. Before discussing the role of the translators of $\mathrm{CNN}$ texts, we might attempt to unveil the subtle difference that we try to draw when using two distinct terms for a process that may seem very similar. To illustrate the point we shall resort to Fairclough's analysis of a Sun report on drug abuse (1995b). The article aimed to transform (or translate, in Fairclough's terms) official jargon into more comprehensible language for the majority of the (obviously native) readers. In this sense, it could be argued that text producers were trying to build linguistic bridges between the government and the newspaper's likely readership. Their role could be regarded, in principle, as that of the "positive mediator", keeping very much in tone with the extended view of the translator.

However, Fairclough underlines other features that offer a very different angle of the resulting text, in particular lexical choices such as «fighting a war» or the use of the phrasal verb «call up». These are terms capable of conjuring up certain images in the popular imagination, taking a clear political stance as regards the issue of drug-trafficking and drug-taking (1995b: 71-72). Their role was, in fact, that of an intermediary between the (very Conservative) news corporation that publishes the Sun newspaper, keen on introducing an ideological perspective on the issue, and its target readership. In the case of the news report on the new law passed by the British government aimed at curbing drug-trafficking and consumption in the UK, the resulting text did not only have an informative function but also a very important persuasive one. Text producers provided their readers with information about the content of the new law and its objectives, but they were also taking sides with a certain interpretation of the anti-drug policies in their own country. Thus, we might refer to mediators as those whose function does not involve a strong ideological manipulation of the source text (understood in the broad sense implied by Fairclough). On the other hand, intermediaries might use the information to instil the text with views that are alien to the discourse of the original but stem from the corporation or from personal convictions and beliefs. That is, the writers might have the interests or ideological position of the corporation in mind, or they might have recourse to their own perception of the world to alter the content, to make readjustments that better suit their own interpretation of the event.

The translators of the two texts analysed were not unaffected by these factors. Firstly, their role was partly hidden in the presentation of CNNenEspañol as a specific service for a Spanish readership. It is true that the target texts were not posted as specifically conceived for Spanish readers, but neither were they identified as translated versions of English texts. The writers were working under ambiguous assumptions, which placed them in an unstable position between the news corporation itself and their function as (invisible) translators. Occasionally they intervened in the source text in order to bring understanding between the two sides, but very often the imposition of edi- 
torial routines over the translational processes resulted in a failure to do so. In the case of the two texts analysed, the manipulation carried out by the translators varied both in goals and results. Both texts share, however, a similar feature: they show no specificity towards the target readership. The choice of texts for a Spanish-speaking readership does not seem to respond to any existing editorial policy about what is relevant for Anglophone readers and what is not. It is true that the political text we have commented upon was relevant not only for a Spanish audience but might also appeal to international readers. After all, it dealt with the issue of terrorism at a time when (particularly) Western nations felt under the threat of new attacks. The appeal of the second text was certainly far more limited.

As for the construction of the texts, we have also noted some differences. The writer/translator of the first article seemed to be working under the pressure of rewriting a target text from various source articles. The time and space allowed was certainly smaller than in the English service so the need to collect and summarize the information left visible marks on the final version. The rearrangement process and the strategies used do not seem to follow clear editorial or translational guidelines and, consequently, the article makes poor reading. Additionally no allowances have been made for the specific needs or interests of the target readers. More dubious is the approach to the second text because it does not merely contravene the recommendations of functional theories, which would require news translators to bear in mind the interests of the readers to receive unbiased reports (Nord, I997: 29), but it blatantly adapts the text to the beliefs and preferences of the text producer. Here the translator has openly influenced the target paper by using transla-

tional strategies that have permitted him to present his sexist interpretation of the news event. Paradoxically enough, it has been the invisibility of the translational process (and not merely of the translator) what has contributed to this regrettable transformation of the original report.

RECIBIDO EN JUNIO 2006 ACEPTADO EN NOVIEMBRE 2006

\section{REFERENCES}

Bassnett, S. (2004). «Trusting Reporters: What Exactly Did Saddam Say?» The Linguist. 43/6, pp. I76-I78.

Bell, A. (I99I). The Language of News Media, Oxford: Blackwell.

Clark, R. and R. Ivanic (I997). The Politics of Writing, London: Routledge.

Fairclough, N. (1992). Discourse and Social Change, London: Polity Press.

Fairclough, N. (1995a). Critical Discourse Analysis: the Critical Study of Language, London \& New York: Longman.

Fairclough, N. (1995b). Media Discourse, London: Arnold.

Fowler, R. (1991). Language in the Nerws, Discourse and Ideology in the Press, London: Routledge.

Fowler, R. (I996). «On Critical Linguistics», in Texts and Practices: Readings in Critical Discourse Analysis, C. R. Caldas-Coulthard and M. Coulthard (eds.), London and New York: Routledge, pp. 3-I4.

Hatim, B. and I. Mason (I990). Discourse and the Translator, Harlow: Longman.

Hatim, B. and I. Mason (I997). The Translator as Communicator, London: Routledge.

Hurtado, S. (2003). El uso del lenguaje en la prensa escrita, Valladolid: Secretariado de Publicaciones de la Universidad de Valladolid.

Kelly, D. (I998). «Ideological Implications of Translation Decisions: Positive Self- and Negative Other Presentation». Quaderns, I, pp. 57-63. 
Language and Intercultural Communication 5/2 (2005). Special Issue on Global Communication.

Leech, G. and J. Svartvik (2002). A Communicative Grammar of the English Language. Harlow: Longman.

Nord, C. (1997). Translating as a Purposeful Activity, Manchester: St. Jerome.

Valdeón, R. A. (2005a). «The Translated Spanish Service of the BBC». Across Languages and Cultures, 6/2, pp. 195-220.

Valdeón, R. A. (2005b). «Media Translation in BBCMundo Internet Texts». Revista Canaria de Estu- dios Ingleses, Special Issue on Translation Studies, 5I, pp. IO5-IIg.

Valdeón, R. A. (2005c). «The CNNenEspañol News». Pespectives: Studies in Translatology, 13/4, pp. $255^{-267}$.

van Dijk, T. A. (1988). News as Discourse, Hillsdale (New Jersey): Lawrence Erlbaum Associates.

Venuti, L. (I995). The Translator's Invisibility, London/New York: Routledge.

Waugh, L. R. (1995). "Reported Speech in Journalistic Discourse: The Relation of Function and Text». Text, I5 /, pp I29-I73. 